Volume 1, Issue 1, 2018, Pages 71-81

\title{
A GIS based assessment of some heavy metal concentrations in milk and rural dairy products in Sohag governorate, Egypt
}

\author{
Ateteallah H.A. ${ }^{a^{*}}$, Mohran M.A. ${ }^{\text {, }}$ Abd El-Khair A.A. ${ }^{a}$, Abed El-Rahim A.M. ${ }^{\text {, }}$ \\ Mustafa A.A. ${ }^{\mathrm{c}}$ \\ ${ }^{a}$ Dairy department, Faculty of Agriculture, Sohag University, Sohag, Egypt \\ ${ }^{b}$ Dairy Department, Faculty of Agriculture, Assiut University, Assiut, Egypt \\ ${ }^{c}$ Soil and Water Department, Faculty of Agriculture, Sohag University, Sohag, Egypt
}

\begin{abstract}
This study was carried out to assess and map some trace elements in raw buffalo's milk and some house made dairy products collected from some villages of Sohag, Egypt. The representative villages named as Nza El-hesh, Enibes, Bnawett, Basona, Abar El-waqf, El-hwaweash, Arab El-sabha, Awlad Salem, El-mgabra and Mzata. Cadmium and lead were measured in More than 180 samples of fresh raw buffalo's milk and house made rural milk products including, Laban Rayeb, Cream, Samna, Kareish cheese and Mish cheese. The spatial variability maps were generated using GIS.
\end{abstract}




\section{Introduction}

In recent years, risks of heavy metals that may pollute different foods have been receiving increased attention. Heavy metal contamination of milk is now considered to be a greater problem than that of pesticides (FAO/WHO, 1997). Pollution of the environment with heavy metals such as lead and cadmium are world-wide problem. Lead alkyl as additives in petrol are combusted and emitted into the atmosphere and can be responsible for the high concentration of lead in some vegetation, roadside, soil, air, water and plants (Burguera et al., 1988). Cadmium was presumed to be a possible source of environmental pollution through galvanized pipes and effluents from electroplating works and geological deposits (Melgar et al., 1997). Maximum limit admitted for Cadmium by Romanian regulation for milk and cheese is $0.05 \mathrm{ppm}$, the maximum limit for lead in milk and cheese in Romania is $0.02 \mathrm{ppm}$ (Florea et al., 2006). Whilst, Codex Alimentarius Commission (2007) established a limit for $\mathrm{Pb}$ in milk 0.02 PPM. Since 1990s, GIS has been claimed as a magic tool in natural resource management "it is ultimate in GIS the perfect answer to each and every resource problem" (Heit and Shortreid, 1991). GIS is a powerful and sophisticated tool for displaying and analyzing spatial relationships between geographic phenomena in the form of vectors and images. With the advent of GIS, there are ample opportunities for a more explicitly reasoned land evaluation. Geographic data as spatial data that "result from observation and measurement of earth phenomena" is referenced to their locations on the earth's surface (Tomlinson, 1987). GIS is an information system including works and links together with the ability to perform numerous tasks utilizing both spatial and attribute data stored in it (ESRI, 2001). It has the ability to integrate variety of geographic technologies like Global Positioning System (GPS), and Remote Sensing (RS). The strength of GIS lies in its ability to integrate different types of data into a common spatial platform. This information should present both opportunities and constraints for the decision maker (Ghafari et al., 2000). Data from different sectors can be integrated into a single analysis without the need for each sector duplicating data collection efforts. The powerful query, analysis and integration mechanism of GIS makes it an ideal scientific tool to analyze it for land use planning. Management of agricultural resources based on their potential and limitation is essential for development of land and other resources on sustainable basis. GIS technology is being increasingly employed by different users to create resource database and to arrive at appropriate solutions/strategies for sustainable development of agricultural resources (Venkataratnam, 2002). The building of a GIS is a chain of operations that leads from planning data observation and collection, to their storage and analysis, to the use of the derived information in some decision making process (Chuong, 2007). From the above mentioned background the objectives of this paper have been formulated for assessment and mapping of some heavy metals contents in milk and rural dairy products in Sohag, Egypt using GIS techniques. 


\section{Materials and methods}

\subsection{Materials}

\subsubsection{Study area}

Sohag area covers part of the Nile Valley, Egypt on the reach extending from the northern edge of Qena governorate at latitude $26007^{\prime} \mathrm{N}$ to the southern edge of Assiut governorate at latitude $26^{\circ} 57^{\prime} \mathrm{N}$. It is bounded between longitudes $31^{\circ} 20^{\prime}$ and $32^{\circ} 14^{\prime} \mathrm{E}$ (Figure 1). The study area belongs to the arid region of North Africa which is generally characterized by hot summer and mild winter with low rainfall. Air temperature ranges between $36.5^{\circ} \mathrm{C}$ (summer) and $15.5^{\circ} \mathrm{C}$ (winter), relative humidity ranges between 51 and $61 \%$ (winter), 33 and $41 \%$ (spring), 35 and $42 \%$ (summer).

\subsubsection{Investigated samples}

Raw buffalo's milk and house - made rural milk products including, Laban Rayeb, Cream, Samna, Kareish cheese and Mish cheese (180 samples) were collected from 10 villages of Sohag governorate. The villages are: Nza Elhesh, Enibes, Bnawett, Basona, Abar Elwaqf, El-hwaweash, Arab El-sabha, Awlad Salem, El-mgabra and Mzata. All investigated raw milk Samples as well as the rural milk products were of buffalo's milk. The above samples were kept under cooling till the application for analysis to determine $\mathrm{Cd}$ and $\mathrm{Pb}$ contents.

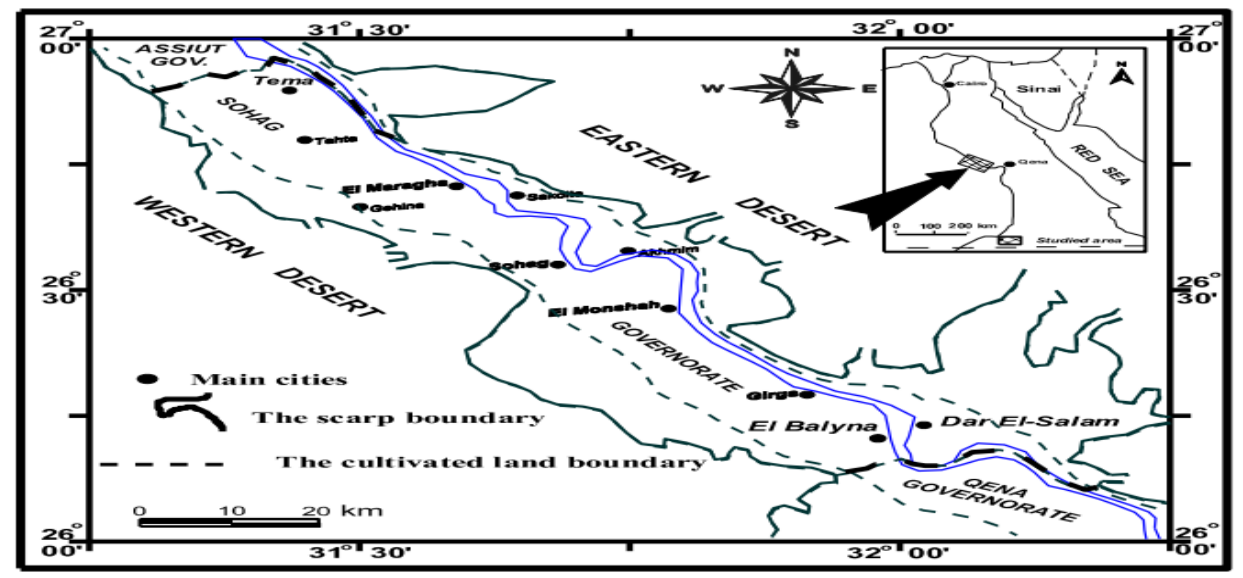

Figure (1): Location map of the study area.

\subsection{Methodology}

\subsubsection{Determination of $\mathrm{Pb}$ and $\mathrm{Cd}$ elements}

The occurrence of $\mathrm{Pb}$ and $\mathrm{Cd}$ elements in samples had been estimated (ppm) according to the method of (James, 1995). The obtained ash was dissolved in $5 \mathrm{ml}$ HCL $(36.6 \%)$ and the volume was completed to $50.0 \mathrm{ml}$ by distilled water. The dilutions were applied to the ICAP6200 (ICP - OES) device to estimate the levels of $\mathrm{Cd}$ and $\mathrm{Pb}$ in Central 
laboratory for Chemical Analysis, Faculty of Agriculture, Assiut University, Egypt.

\subsubsection{Generation of thematic maps}

Inverse Distance Weighted (IDW) interpolation determines cell values using a linearly weighted combination of a set of sample points. The weight is a function of inverse distance. IDW lets the user control the significance of known points on the interpolated values, based on their distance from the output point. Thematic maps were generated for each of the parameters using IDW interpolation provided in Arc GIS 9.3 software developed by ESRI (2011).

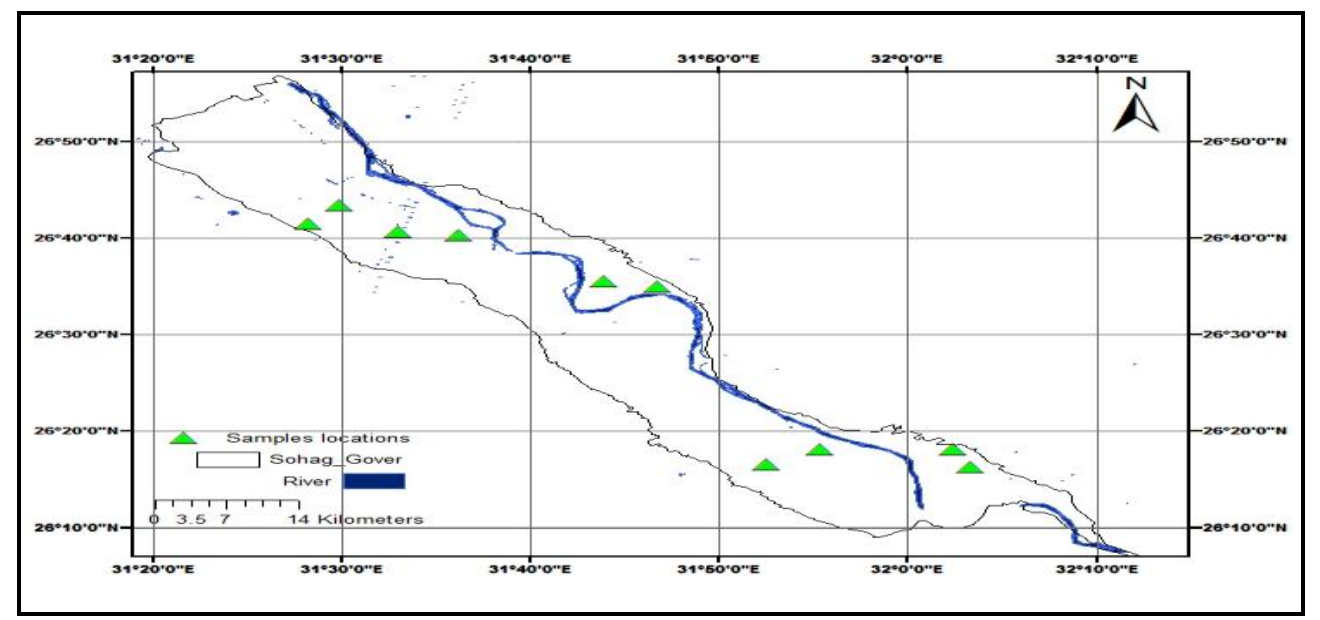

Figure (2): Location map of the samples.

\section{Results and Discussion}

\subsection{Cadmium element $(C d)$ contents}

Results listed in Table (1) revealed that, the mean value of $\mathrm{Cd}$ level in raw buffalo's milk was $0.022 \mathrm{ppm}$. The obtained results were similar to those obtained by El-Gendy et al. (2007), who found that the $\mathrm{Cd}$ levels in Assiut governorate were $0.027 \mathrm{ppm}$ at Arab ElMadabigh region and $0.020 \pm 0.013 \mathrm{ppm}$ at Assiut University Station, while it was higher than that obtained by Sharkawy and Hussein (2002) (0.174 ppm); Elprince and Sharkawy (1999) (0.019 ppm) and Enb et al. (2009) (0.118 ppm). On the other hand, data obtained by Amer et al. (2005) (0.353 ppm) was higher than the present level. The mean value of $\mathrm{Cd}$ level in samples of Laban Rayeb lied between 0.017 and $0.030 \mathrm{ppm}$ for samples obtained from Arab El-sabha and Mzata villages, respectively; with an average of $0.021 \mathrm{ppm}$. The mean value of Cd levels in traditional Cream samples was ranged from $0.015 \mathrm{ppm}$ for samples of Nza Elhesh village to $0.028 \mathrm{ppm}$ for that of Mzata village, with an average of 0.020 
ppm, which was lower than values obtained by Amer et al. (2005), who stated that the $\mathrm{Cd}$ contents in cream was $0.088 \mathrm{ppm}$. Generally, the variation of $\mathrm{Cd}$ levels in cream samples regarded to various investigated villages may be due to the environmental conditions related to each village.

Table (1): Cadmium concentrations of different raw buffalo's milk and milk products collected from some villages of Sohag governorate, Egypt*

\begin{tabular}{lcccccc}
\hline & \multicolumn{7}{c}{ Cd $(\mathrm{ppm})$} \\
\cline { 2 - 7 } & Raw milk & Laban Rayeb & Cream & Samna & Kareish cheese & Mish cheese \\
\hline Nza El-hesh & 0.036 & 0.020 & 0.015 & 0.018 & 0.047 & 0.072 \\
Enibes & 0.018 & 0.018 & 0.021 & 0.018 & 0.064 & 0.068 \\
Bnawett & 0.017 & 0.018 & 0.018 & 0.017 & 0.045 & 0.022 \\
Basona & 0.025 & 0.020 & 0.017 & 0.032 & 0.077 & 0.081 \\
Abar El-waqf & 0.019 & 0.017 & 0.022 & 0.018 & 0.069 & 0.044 \\
El-hwaweash & 0.017 & 0.024 & 0.021 & 0.019 & 0.020 & 0.018 \\
Arab El-sabha & 0.017 & 0.019 & 0.017 & 0.017 & 0.049 & 0.070 \\
Awlad Salem & 0.017 & 0.021 & 0.020 & 0.020 & 0.076 & 0.018 \\
El-mgabra & 0.025 & 0.020 & 0.024 & 0.027 & 0.046 & 0.070 \\
Mzata & 0.025 & 0.030 & 0.028 & 0.025 & 0.065 & 0.053 \\
Average & 0.022 & 0.021 & 0.020 & 0.021 & 0.056 & 0.051 \\
\hline
\end{tabular}

Data presents in Table (1) represent the mean value of $\mathrm{Cd}$ concentrations samples of Samna ranged from $0.017 \mathrm{ppm}$ for Samples obtained from both of Bnawett and Arab El-sabha villages to $0.032 \mathrm{ppm}$ for that from Basona village. The average value of $\mathrm{Cd}$ contents of Kareish cheese samples was $0.056 \mathrm{ppm}$, which was lower than that obtained by Mohran et al. (2010) and Bakry (2012), while Abdou and Korashy (2001) had not detected Cd in Kareish cheese collected randomly from different localities of Upper Egypt. The determined values of $\mathrm{Cd}$ contents in Mish cheese samples obtained from various villages listed in Table 1. It was found that, Mish cheese samples collected from Basona village recorded the highest value with $0.081 \mathrm{ppm}$, while the lowest one was found in samples of both Elhwaweash and Awlad Salem with 0.018 ppm. The mean values of all samples gave 0.051 . The obtained data can be represent in graphically form by using GIS (Figure 3). At a first glance, there were recorded values above safe limits for $\mathrm{Cd}$ in Kareish and Mish cheeses. Contrary to that, all recorded under safe limits for $\mathrm{Cd}$ in other products. Generally, the variation of $\mathrm{Cd}$ high levels in Cream samples regarded to various investigated villages may be due to the environmental conditions related to each village. The results highlight the most probable hot spots areas that increase the human health problems. Also, these areas could be distinctly targeted/prioritized on maps. This type of regional scale (spatial) information is in fact highly desired by the decision makers for achieving sustained/increased the quality of these milk products. 


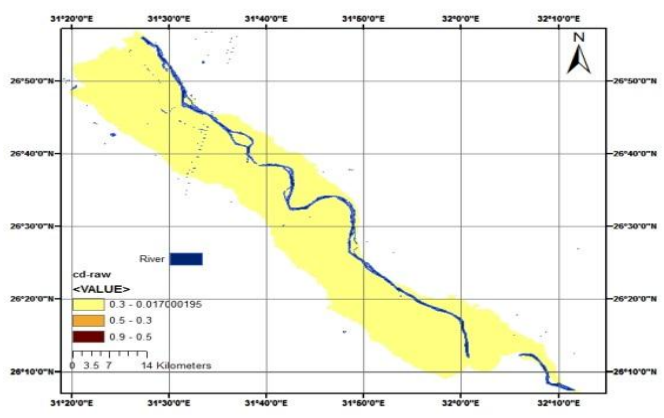

1. Raw milk

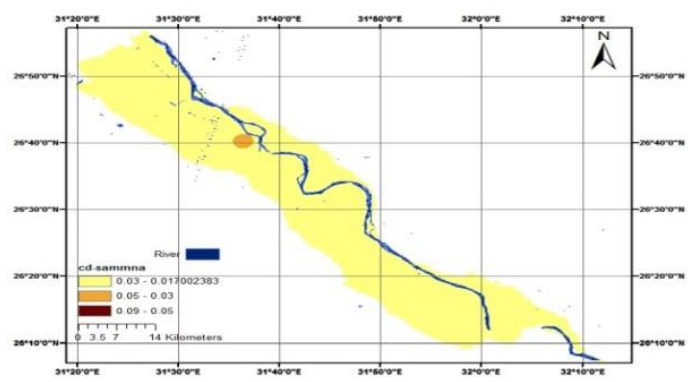

3. Samna

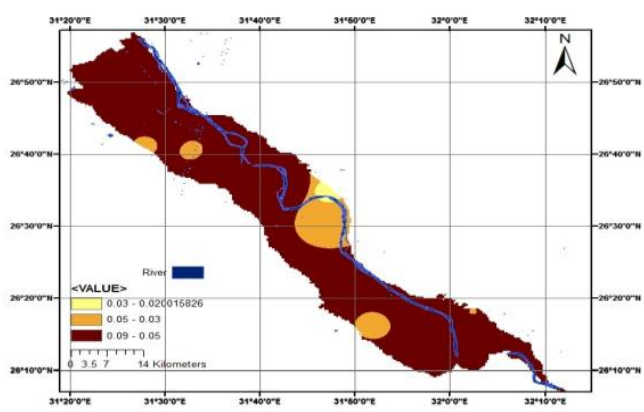

5. Karish cheese

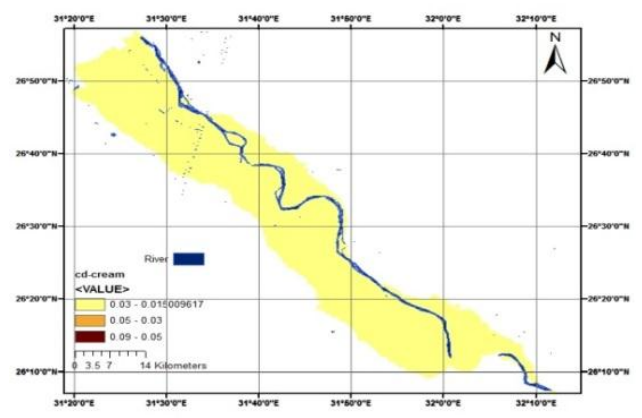

2. Cream

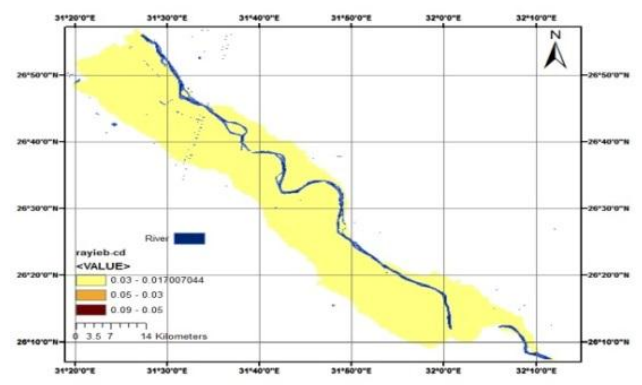

4. Rayib

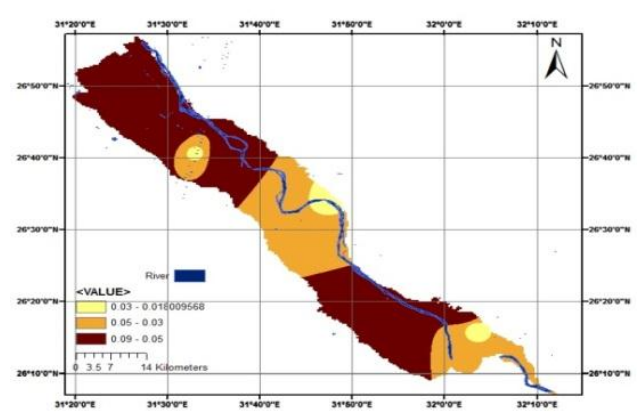

6. Mish cheese

Figure (3): Cd concentrations in the samples collected from the study areas.

\subsection{Lead element $(\mathrm{Pb})$ contents}

The lead concentrations of raw buffalo's milk samples obtained from various villages related to Sohag governorate are presented in Table (2). The mean value of $\mathrm{Pb}$ level in raw buffalo's milk was 0.098 ppm. The obtained data of $\mathrm{Pb}$ concentration was nearly similar to those obtained by Enb et al. (2009) (0.084 
ppm), while it was higher than results reported by Sreedhar et al. (2009) (0.015 ppm). On the other hand, it was lower than those reported by El-Gendy et al. (2007) (0.156 to $0.264 \mathrm{ppm})$. Moreover, both Arab El-sabha and El-mgabra villages showed the lowest values with 0.010 and 0.013 ppm, respectively; while the highest one was given by raw milk samples of Nza El-hesh village with 0.484 ppm. The mean value of lead contents in samples of Laban Rayeb lied between 0.015 and $0.205 \mathrm{ppm}$ for samples obtained from Basona and Nza El-hesh villages, respectively; with an average of $0.070 \mathrm{ppm}$. As indicated in Table 2, the mean values of $\mathrm{Pb}$ levels in traditional Cream samples are ranged from 0.023 ppm for samples of El-hwaweash village to $0.215 \mathrm{ppm}$ for that of Enibes village, with an average of $0.087 \mathrm{ppm}$, which was lower than values obtained by Amer et al. (2005), who stated that the Pb contents in Cream was $0.492 \mathrm{ppm}$. From results listed in Table 2, it could be noticed that the mean value of lead concentrations of
Samna (0.84 ppm) was nearly similar to that of Cream $(0.084 \mathrm{ppm})$. The value obtained from samples of Bnawett village was the highest with 0.183 ppm, while the lowest concentration was given by sample belonged to Mzata village with 0.025 ppm. As shown in Table (2), the average of $\mathrm{Pb}$ contents in Kareish cheese samples was $1.681 \mathrm{ppm}$, which varied from 0.159 ppm that given by samples obtained from El-hwaweash village to $2.506 \mathrm{ppm}$ for samples of Arab El-sabha village. Moreover, it was observed that the values of sample from Awlad Salem and Enibes villages showed nearly the same levels of 1.872 and $1.855 \mathrm{ppm}$, respectively. The present mean value of $\mathrm{Pb}$ content of Kareish cheese samples was higher than that obtained by Mohamed (2008) and Bakry (2012), while it was lower than that obtained by Mohran et al . (2010). The Pb values in Mish cheese samples collected from different villages related to Sohag governorates were listed in Table 2. It was found that, the average level of $\mathrm{Pb}$ contents was $1.654 \mathrm{ppm}$.

Table (2): Lead concentration of different raw buffalo's milk and milk products collected from some villages of Sohag governorate, Egypt ${ }^{*}$.

\begin{tabular}{lcccccc}
\hline & \multicolumn{7}{c}{$\mathrm{Pb}(\mathrm{ppm})$} \\
\cline { 2 - 6 } & Raw milk & Laban Rayeb & Cream & Samna & Kareish cheese & Mish cheese \\
\hline Nza El-hesh & 0.484 & 0.205 & 0.099 & 0.123 & 1.206 & 4.965 \\
Enibes & 0.114 & 0.112 & 0.215 & 0.108 & 1.855 & 1.350 \\
Bnawett & 0.067 & 0.072 & 0.102 & 0.183 & 0.872 & 0.162 \\
Basona & 0.090 & 0.015 & 0.072 & 0.107 & 2.456 & 2.474 \\
Abar El-waqf & 0.055 & 0.042 & 0.171 & 0.093 & 2.103 & 1.337 \\
El-hwaweash & 0.031 & 0.105 & 0.023 & 0.103 & 0.159 & 0.097 \\
Arab El-sabha & 0.010 & 0.017 & 0.030 & 0.026 & 2.506 & 2.188 \\
Awlad Salem & 0.029 & 0.038 & 0.037 & 0.043 & 1.872 & 0.094 \\
El-mgabra & 0.013 & 0.048 & 0.040 & 0.029 & 1.988 & 2.678 \\
Mzata & 0.090 & 0.044 & 0.081 & 0.025 & 1.790 & 1.190 \\
Average & 0.098 & 0.070 & 0.087 & 0.084 & 1.681 & 1.654 \\
\hline
\end{tabular}

*Values are average of three samples.3.5 Soil salinity (EC). 


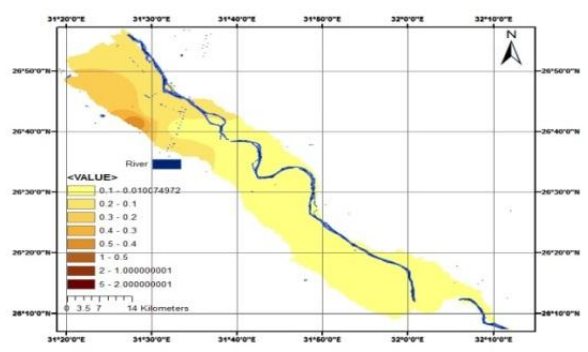

7. Raw milk

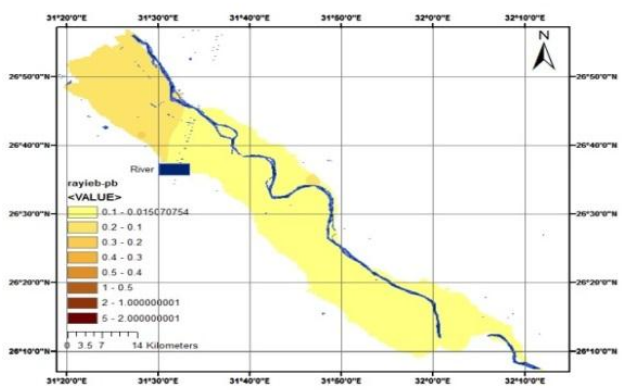

9. Rayib

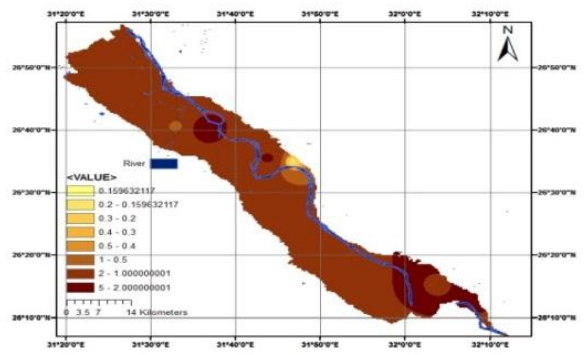

11. Karish cheese

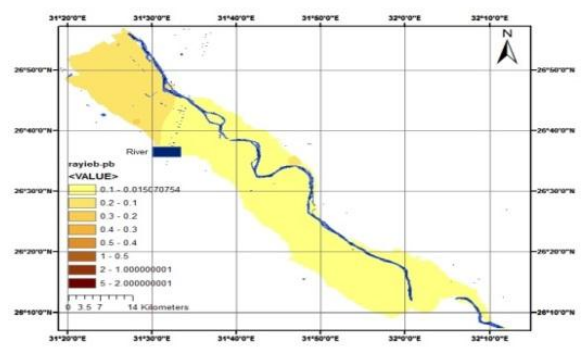

8. Cream

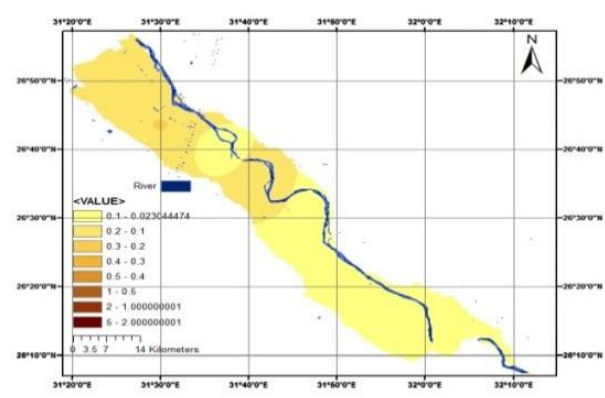

10. Samna

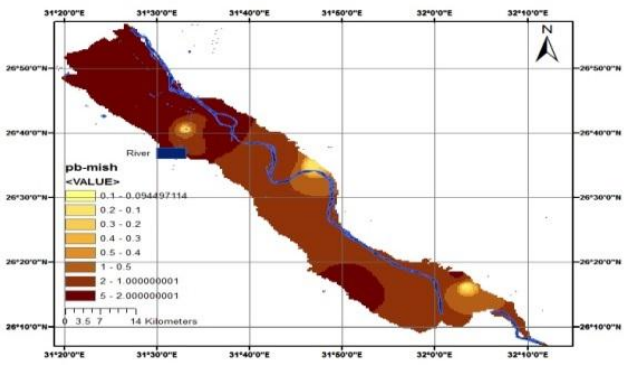

12. Karish cheese

Figure (4): Pd concentrations in the samples collected from the study areas.

As mentioned in $\mathrm{Cd}$ results, $\mathrm{Pd}$ levels have the same trend in all examined samples. But, the increased levels of $\mathrm{Pb}$ in Kareish and Mish were very high exceeded 20 times the safe limits in some places (Figure 4).

\section{Conclusions}

This is a pioneer study documented the some heavy metals load in the milk products in Sohag. The study revealed that levels of $\mathrm{Cd}$ and $\mathrm{Pb}$ in raw milk and 
its different products were above safe limits in both Mish cheese and Kariesh cheese. These findings have serious implication for public health. The results highlight the most probable hot spots areas that increase the human health problems. Also, these areas could be distinctly targeted/prioritized on maps. This type of regional scale (spatial) information is in fact highly desired by the decision makers for achieving sustained/increased the quality of these milk products.

\section{References}

Abdou, K. A. and Korashy, E. (2001), "Lead, cadmium and manganese in milk and some milk products in Upper Egypt", Assiut Veterinary Medical Journal, Vol. 45, No. 89, pp. 336-348.

Amer, I. H., El Sayed, M. S. and Abd-El Aal, S. F. (2005), "The Preliminary Content of Heavy Metal Residues in Raw Cow's Milk and Its Distribution in Some Dairy Products", Zagazig Veterinary Journal, Vol. 33, No. 1, pp. 263271.

Bakry, S. S. (2012), "Heavy metals residues in milk and certain rural dairy products in some Assiut villages", Ph.D. Thesis, Faculty of Agriculture, Assiut University, Assiut, Egypt.
Burguera, J. L., Burguera, M.and Rondon, C. (1988), "Lead content in hair, as related to petrol-lead exposure in Merida City, Venezuela", Science of The Total Environment, Vol. 77, No. 1, pp. 45-49.

Chuong, M. (2007), "Multi criteria land suitability evaluation for selected fruit crops in hilly region of Central Vietnam", Ph.D. thesis, Humboldt University of Berlin, Germany.

Codex Alimentarius Commission, (CAC) (2007), "Joint FAO/WHO food standards programme", The Twenty-eighth Session of the Codex Committee on Methods of Analysis and Sampling, Budapest, Hungary.

El-Gendy, S. M., Mohran, M. A., Hanafy, N. and Mohamed, T. H. (2007), "Studies on chemical pollutants of milk produced in Assiut Vicinity", the $10^{\text {th }}$ Egyptian conference for dairy Science \& Technology, the international agricultural center, Cairo, Egypt, pp. 121-133.

El-Prince, E. and Sharkawy, A. A. (1999), "Estimation of some heavy metals in bovine milk in Assiut governorate", Assiut Veterinary Medical Journal, Vol. 41, No. 81, pp. 153-169.

Enb, A., Abou Donia, M. A., AbdRabou, N. S., Abou-Arab, A. A. K. and El-Senaity, M. H. (2009), "Chemical composition of raw milk 
and heavy metals behavior during processing of milk products", Global Veterinaria, Vol. 3, No. 3, pp. 268275.

ESRI (Environmental Systems Research Institute) (2001), "ArcInfo Manual Version 7.0, Cell-based modeling with GRID" Environmental Systems Research Institute, Redlands, California, USA, 630 pp.

ESRI (2011), "ArcGIS Desktop: Release 9.3.", Redlands, California, USA.

FAO/WHO (1997), "General requirements (Food Hygiene)", Vol. 1B (supplement), Codex Alimentarius, Food and Agriculture Organization, Rome, Italy.

Florea, T., Huszti, S. O. and Costin, Gh. M. (2006), "Heavy metal contaminants in milk and cheese", the annals of the university Dunarea de Jos of Galati, Fascicle VI Food Technology, Galati University Press, Romania.

Ghafari, A., Cook, H. F. and Lee, H. C. (2000), Integrating climate, soil and crop information: a land suitability study using GIS. The $4^{\text {th }}$ Int. Conference on Integrating GIS and Environmental Modelling (GIS/EM4): Problems, Prospects and Research needs, Banf, Alberta, Canada

Heit, M. and Shortreid, A. (1991), GIS Applications in Natural Resource: Colorado, GIS World. PP. 540.
James, C.S. (1995), "Analytical Chemistry of Foods", Blackie Academic and Professional, London, England.

Melgar, M. J., Perez, M., Garcia, M. A., Alonso, J. and Miguez, B. (1997), "The toxic and accumulative effects of short-term exposure to cadmium in rainbow trout (Oncorhynchus mykiss)", Veterinary and Human Toxicology Journals, Vol. 39, No. 2, PP. 79-83.

Mohamed, T. H. (2008), "Fate of certain trace elements in milk during the manufacturing of some dairy products", Ph.D. Thesis, Faculty of Agriculture, Assiut University, Assiut, Egypt.

Mohran, M. A., El-Gendy, S. M., Said, A. I. and Mohamed, T. H. (2010), "The occurrence of certain elements in milk and some dairy products. IThe levels of $\mathrm{Zn}, \mathrm{Fe}, \mathrm{Cd}$ and $\mathrm{Pb}$ in raw milk and some dairy products", The $5^{\text {th }}$ Scientific Conference of Agricultural Sciences, Faculty of Agriculture, Assiut University, Assiut, Egypt.

Sharkawy, A. A. and Hussein, M. Sh. (2002), "Estimation of some metallic pollutants in milk and milk powder in Beni-Suef governorate", Assiut Veterinary Medical Journal, Vol. 47, No. 94, pp. 211-232.

Sreedhar, N. Y., Reddy Prasad, P., Sankara Nayak, M., Rekha, D. and Nageswara Reddy, C. (2009), 
"Differential pulse polarographic determination of $\mathrm{Cd}$ (II) and $\mathrm{Pb}$ (II) in milk samples after solid-phase extraction using Amberlite XAD-2 Resin modified with 2,2'-DPED $3 \mathrm{P}^{\prime \prime}$, Journal of the Chinese Chemical Society, Vol. 56, pp. 1139-1146.

Venkataratnam, L. (2001), "Remote sensing and GIS in agricultural resources management", Proceeding of the first National Conference on Agro-Informatics, Indian Society of Agricultural Information Technology (INSAIT), Dharwad, Karnataka, India, pp. 20-29.
Tomlinson, R. F. (1987), "Current and potential uses of geographical information systems: The North American experience", International Journal of Geographical Information Systems, Vol. 1, pp. 203-218. 